\title{
TEACHERS' PERCEPTIONS ABOUT USE AND CHALLENGES OF HANDS-ON ACTIVITIES IN SECONDARY SCIENCE CLASSROOM
}

\author{
Tasnim Musharrat ${ }^{\mathrm{i}}$ \\ Lecturer, \\ Institute of Education and Research, \\ University of Chittagong, \\ Bangladesh
}

\begin{abstract}
:
Learning through hands-on activities is very effective and influential for both feeling and emotion of students. The purpose of the study is to identify teachers' perceptions about use and challenges regarding hands-on activities. A qualitative approach has been followed to find answers to the research questions. Data have been collected through convenient sampling from two schools of Narayanganj. One open-ended questionnaires and semi-structured interviews with teachers' were used in the data collection process. This study finds that teachers' less awareness about conducting hands-on activities in the science classes. Class loads, development of teaching materials, exam-based evaluation system, lack and unavailability of teaching aids are some major challenges. Findings of this study have several implications for teachers' professional development and teachers' training program. Suggestions are made that a supportive collegial and administrative medium allow teachers to change their own personal constructs about teaching learning.
\end{abstract}

Keywords: hands-on activity, teachers' awareness, teaching materials

\section{Introduction}

Hands-on experiences significantly advance learning at all levels of science education when appropriately designed and guided by qualified educators (American Chemical Society, Public Policy Statement 2017-2020).

Hands-on in general means learning by experience. It is assumed that working in a hands-on way provides a more realistic and exciting experience of the content (Franklin and Peat, 2005; Nott and Wellington, 1996). Most empirical studies provide evidence for the assumption that conducting hands-on activities leads to positive motivational outcomes (Holstermann, N., Grube, D. \& Bögeholz, S., 2010).

\footnotetext{
i Correspondence: email tasnimmusharrat@cu.ac.bd
} 
Hands-on activity is a very new concept for Bangladesh. Most empirical studies indicate that practical work is beneficial for students' motivation, we hypothesized that in general, students with experience in hands-on activities will show higher interest in these activities than students without experience (Holstermann, N., Grube, D. \& Bögeholz, S., 2010). However, most of the previous studies focused on practical work in general and did not look for differences between particular hands-on activities. This constitutes a shortcoming in research, since there is a large amount of diversity in handson activities. Different activities make various demands on students. (cf. Lumpe and Oliver, 1991). Hands-on activities can also vary in terms of time allowed for them, teachers' organisational skills, or the social and emotional climate of the class (Gardner and Gauld, 1990).

\section{Literature Review}

Hands-on science is defined mainly as any instructional approach involving activity and direct experience with natural phenomena or any educational experience that actively involve students in manipulating objects to gain knowledge or understanding (Haury \& Rillero, 1994). Hands-on activities let the students' minds grow and learn based on the experiences and the environment while discussing, investigating, creating, and discovering with other students. Hands on activities encourage both teachers and students' creativity in problem solving, promote student independence, improves skills such as specifically reading, arithmetic computation, and communication (Haury \& Rillero, 1994; Staver \& Small, 1990). Lebuffe (1994) emphasizes that children learn better when they can touch, feel, measure, manipulate, drawing, making charts, record data and when they find answers for themselves rather than being given the answer in a textbook or lecture. According to the U.S. National Science Education Standards (1995), students should have minds-on and/or heads-on experiences during hands-on activities. While doing hands-on activity, the learner is learning by doing but while minds-on learning, the learner is thinking about what she or he is learning and doing. Hofstein and Lunetta (1982) state that a minds-on science activity includes the use of higher order thinking, such as problem solving compared to the hands-on activity. Therefore, students should be both physically and mentally engaged in activities that encourage learners to question and devise temporarily satisfactory answers to their questions (Victor \& Kellough, 1997).

\section{Research Problem}

During my M.Ed. thesis and school observation experience, I have found that teachers did not practice hands-on activities effectively. Rather they prefer to go through the suggested hands on activity part only by reading the whole section. And maximum teachers think that practicing hand on activity in the class is just a waste of class time. 


\subsection{Purpose Statement}

The purpose of the study is to identify the reasons behind teachers' attitude about effective use of hands-on activities and challenges in doing hands-on activities in secondary school science classroom in Bangladesh.

\subsection{Research Questions}

This research tried to explore current practice and challenges of suggested hands-on activities in secondary science classes to promote students' higher order learning. To achieve this purpose, this study will try to find out the following questions:

1. How teachers explain the implementation of suggested hands-on activities in the science classrooms?

2. What are the challenges of teachers' to practice hands-on activities in the classroom?

\section{Methodology}

\subsection{Nature of the Study}

This study is a qualitative approach. Qualitative data tried to explain for eliciting the findings to gain insights about the teachers' practice and challenges of doing effective hands-on activities. This helped to maintain the validity of the findings. Data collection was done from secondary science teachers'.

\subsection{Instruments}

\subsubsection{Interview}

Semi structured interview guideline was used to explore secondary science teachers' opinion about the effectiveness of hands-on activities in the science classrooms to promote students' critical and logical thinking.

\subsubsection{Questionnaires}

Open-ended questionnaires were used to understand secondary teachers' thinking about the relevance of hands-on activities with their textbook lesson to achieve higher order learning. These questionnaires were developed by the researcher according to Bloom's taxonomy of cognitive development on the particular practical work that was observed.

\subsection{Sample \& Sampling}

The sample of the study was consisted of four secondary science teachers' of two secondary schools of Narayanganj. Teachers were selected through convenient sampling process.

\subsection{Data Analysis Techniques}

As qualitative method was followed to conduct the research, so Explanatory technique was used for the data analysis (Creswell, 2012). The qualitative data was analyzed in 
narrative approach to illustrate the emerged patterns and themes in the practice and context. Finally, data were compared to identify the findings of this study.

\section{Findings}

Some external factors including teachers' role play have significant amount of influence on doing hands-on activities in science classrooms. Their internal activities also play significant role on their doing hands on activities, their opinion and acceptability about it and the linkages with their regular life which we see from the result. Hands-on activities inspire all students to increase their standards for learning and participation because of the engagement of multiple senses. They believe that they can consciously and more actively participate in the learning process. Examining the research questions, the study found some points from the responses of the participants as follows:

- Many of the practitioners need encouragement to try hands-on data activities. Through practice the right balance between fun and learning it can be achieved. Facility for exploration and discovery motivate students to be self-directed learners. It is advantageous for both motivation and the ability to acquire new knowledge that students be able to direct their own learning (Fischer, 1991).

- In maximum cases feedback sessions from teachers' and fellows were not found. Researcher could not find anything like drawing a situation or problem and solving it in participatory way. The quality of experience during task completion is an important factor for the development of students' intrinsic motivation (Krapp, 2005). Interest development will occur if a person experiences his or her actual engagement on the basis of cognitive-rational and emotional evaluations in a positive way (Krapp, 2005). In this study the researcher found lacking in this case.

- Hands-on data activities and Activities Based Learning require teachers' to think on their feet. But maximum teachers were not ready to leave the shade of tradition teaching practice. They were not aware about the development of students' logical and critical thinking. The development of thinking and reasoning processes is stressed more than the acquisition of specific knowledge (Staub and Stern, 2002). Teachers and students both were practicing just spoon feeding. Teachers were not aware about evaluate the difference between students' beliefs and actual empirical results.

- Teachers do not get the scope to prepare for the classes properly. Science teachers needed sufficient preparation (Rahman, 2011). During this study participant teachers shared that they hardly get proper scope and time for class preparation and mentioned it as a challenge.

- Teachers agreed with the idea that capabilities and attention of students are not the same. But student numbers of the classrooms are huge to the perspective of Bangladesh. Teachers claimed that it could be difficult to actively involve this huge 
numbers of students through hands-on activities. Teachers' ideas of conducting effective lesson in the large classroom were not cleared.

- Providing adequate instructions for conducting hands-on activities and using sufficient amount of learning resources became a great challenge in this case. Most of the time teaching materials/aids had less relevancy for activities in science classes. Students get least chances to use materials to do hands on activities. According to the study of Goodrum (2004), that in explore phase teachers should provide opportunity to students to interact directly with material, concept, problem and phenomena through hands-on activities.

- During this research, Teachers mentioned workload, pressure from school authorities, time constraint are barriers in practicing Hands-on activity in regular basis. Baker and Silva (cited in Joyner \& Molina, 2012) focused that time is a factor in science classes. According to them, time management depends on curriculum, teaching practices and efficiency of the teacher, culture of students.

\section{Recommendations}

Hands-on activities do not replace traditional methods but can complement the teachinglearning process. Teachers can provide more emphasis on locally made low cost apparatus. A certain level of flexibility must be available for the teachers.

This study recommends that teachers' manual and training program on Hands-on activities need to be introduced immediately. Policy maker must be conscious about providing the scope for arranging proper training, training module to make teachers' skilled about the processes. Consecutive training program can be arranged with small gaps between two sessions. Through the study, teachers' may get the idea to be respectful to the diverse talents and their different ways of learning. Individual idea construction of the students can be emphasized in teachers' practice. Future directions for this particular study include using different analyses.

\section{Conclusion}

Students' learn both content and thinking strategies by investigating the subject matter through hands-on activities. Hands-on activities support problem-based approaches to learning by focusing on the experience and process of investigating, proposing and creating solutions. For students to truly learn science concepts, teachers' and students' both need practical opportunities to apply knowledge and also need help in integrating or exchanging the knowledge they gain. The importance of student investigation of basic scientific principles cannot be overstated.

In the above literatures shows that when educators take use of hands-on activities in a positive way, it increases student engagement, creativity, critical thinking, first hand skills and make the teaching learning process more effective. Supportive and interactive collegial network of teachers can bring a significant change. 


\begin{abstract}
About the Author
Tasnim Musharrat is a lecturer in the Institute of Education and Research, University of Chittagong, Bangladesh. Her research interests are Science Education through Hands-on activities, STEM Education, Activity-based Learning, Self-directed Student-centric learning.

ORCID iD: orcid.org/0000-0002-1448-7329,

Correspondence concerning the article should be addressed to: Tasnim Musharrat, Institute of Education and Research, University of Chittagong, Chittagong University road, Hathhazari, Chittagong - 4331, Bangladesh. Email: tasnimmusharrat@cu.ac.bd.
\end{abstract}

\title{
References
}

Ambrose, S. A., Bridges, M. W., DiPietro, M., Lovett, M. C., \& Norman, M. K. (2010). How learning works: 7 research-based principles for smart teaching. San Francisco, CA: Jossey-Bass.

Baker, R. S. J. D. (2007). Modeling and Understanding Students' Off-task Behavior in Intelligent Tutoring Systems. Proceedings of ACM CHI 2007: Computer-Human Interaction, 1059-1068. New York: ACM.

Creswell, J. W. (2012). Educational research: Planning, conducting, and evaluating quantitative research (3rd ed.). New Jersey: Pearson Education, Inc.

Fischer, G. (1991). "Supporting Learning on Demand with Design Environments." In L. Birnbaum (Ed.), International Conference on the Learning Sciences (Evanston, IL), Association for the Advancement of Computing in Education, pp. 165-172.

Franklin, S., \& Peat, M. (2005). Virtual versus real: an argument for maintaining diversity in the learning environment. International Journal of Continuing Engineering Education and Life Long Learning, 15, 67-78.

Gardner, P., \& Gauld, C. (1990). Lab work and students' attitudes. In E. Hegarty Hazel (Ed.), The student laboratory and the science curriculum (pp.132-156).London: Routledge.

Goodrum, D. (2004). Teaching strategies for Science Classrooms. In G. Venville \& V. Dawson (Eds.), The art of teaching science (1st ed., pp. 54-72).

Haury, D. L. \& Rillero, P. (1994). Perspectives of hands-on science teaching. Retrieved from http://www.ncrel.org/sdrs/areas/issues/content/cntareas/science/eric/erictoc.html.

Hoffmann \& P. Gardner (Eds.). Interests in science and technology education (pp.15-34). Kiel: Institute for Science Education (IPN).

Holstermann, N., Grube, D. \& Bögeholz, S. Hands-on Activities and Their Influence on Students' Interest. Res Sci Educ 40, 743-757 (2010). https://doi.org/10.1007/s11165009-9142-0.

Hofstein, A. \& Lunetta, V. N. (1982). The role of the laboratory in science teaching: Neglected aspects of research. Review of Educational Research, 52(2), 201-217. 
Indiana University (2006). Experiential learning notations on Indiana University official transcripts. Retrieved from http://registrar.iupui.edu/experiential-learning.html.

Joyner, S., \& Molina, C. (2012). Class Time and Student Learning. Austin. TX: SEDL.

Krapp, A. (2005). Basic needs and the development of interest and intrinsic motivational orientations. Learning and Instruction, 15, 381-395.

Lebuffe, J. R. (1994). Hands-on science in the elementary school. East Lansing, MI: National Center for Research on Teacher Learning (ERIC Document Reproduction Service No. ED 375003).

Lumpe, A. T., \& Oliver, J. S. (1991). Dimensions of hands-on science. The American Biology Teacher, 53, 345-348.

Moore, D. T. (2010). Forms and issues in experiential learning. In D. M. Qualters (Ed.) New Directions for Teaching and Learning (pp. 3-13). New York City, NY: Wiley.

Nott, M., \& Wellington, J. (1996). When the black box springs open: practical work in schools and the nature of science. International Journal of Science Education, 18, 807818.

Rahman, S. M. H. (2011). Professional learning of secondary science teachers in Bangladesh. Unpublished doctoral dissertation, Monash University, Melbourne, Australia.

Staub, F. C., \& Stern, E. (2002). The nature of teachers' pedagogical content beliefs matters for students' achievement gains: Quasi-experimental evidence from elementary mathematics. Journal of Educational Psychology, 94(2), 344-355.

The University of Texas at Austin College of Natural Sciences (2013). Freshman Research Initiative. Retrieved from http://cns.utexas.edu/fri.

U.S. National Science Education Standards (1995). National science education standards: An overview. Washington, D. C.: National Academy Press. Retrieved from http://books.nap.edu/html/nses/html/overview.html\#organization.

Victor, E. \& Kellough, R. D. (1997). Science for the elementary and middle school (8th ed.). Upper Saddle River, New Jersey: Prentice Hall.

Wurdinger, D. D., \& Carlson, J. A. (2010). Teaching for experiential learning: Five approaches that work. Lanham, MD: Rowman \& Littlefield Education. 
Tasnim Musharrat

TEACHERS' PERCEPTIONS ABOUT USE AND CHALLENGES OF

HANDS-ON ACTIVITIES IN SECONDARY SCIENCE CLASSROOM

Creative Commons licensing terms

Author(s) will retain the copyright of their published articles agreeing that a Creative Commons Attribution 4.0 International License (CC BY 4.0) terms will be applied to their work. Under the terms of this license, no permission is required from the author(s) or publisher for members of the community to copy, distribute, transmit or adapt the article content, providing a proper, prominent and unambiguous attribution to the authors in a manner that makes clear that the materials are being reused under permission of a Creative Commons License. Views, opinions and conclusions expressed in this research article are views, opinions and conclusions of the author(s). Open Access Publishing Group and European Journal of Education Studies shall not be responsible or answerable for any loss, damage or liability caused in relation to/arising out of conflicts of interest, copyright violations and inappropriate or inaccurate use of any kind content related or integrated into the research work. All the published works are meeting the Open Access Publishing requirements and can be freely accessed, shared, modified, distributed and used in educational, commercial and non-commercial purposes under a Creative Commons Attribution 4.0 International License (CC BY 4.0). 